\title{
Assessing the solar irradiation potential for solar photovoltaic applications in buildings at low latitudes - Making the case for Brazil
}

\author{
Joara Cronemberger ${ }^{\mathrm{a}, *}$, Estefanía Caamaño-Martín ${ }^{\mathrm{b}}$, Sergio Vega Sánchez ${ }^{\mathrm{a}}$

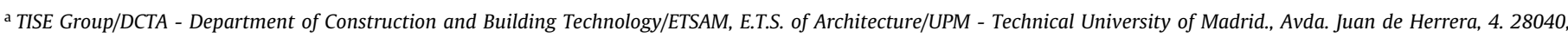 \\ Madrid, Spain \\ ${ }^{\mathrm{b}}$ IES - Institute of Solar Energy- Technical University of Madrid., Avda. Ciudad Universitaria s/n. 28040, Madrid, Spain
}

\section{A R T I C L E I N F O}

\section{Article history:}

Received 22 February 2012

Received in revised form 23 August 2012

Accepted 29 August 2012

\section{Keywords:}

Building-integrated photovoltaics (BIPV)

Building envelope

Orientation

Tilt

Losses

\begin{abstract}
A B S T R A C T
In Brazil, a low-latitude country characterized by its high availability and uniformity of solar radiation, the use of PV solar energy integrated in buildings is still incipient. However, at the moment there are several initiatives which give some hints that lead to think that there will be a change shortly. In countries where this technology is already a daily reality, such as Germany, Japan or Spain, the recommendations and basic criteria to avoid losses due to orientation and tilt are widespread. Extrapolating those measures used in high latitudes to all regions, without a previous deeper analysis, is standard practice. They do not always correspond to reality, what frequently leads to false assumptions and may become an obstacle in a country which is taking the first step in this area. In this paper, the solar potential yield for different surfaces in Brazilian cities (located at latitudes between $0^{\circ}$ and $30^{\circ} \mathrm{S}$ ) are analyzed with the aim of providing the necessary tools to evaluate the suitability of the buildings' envelopes for photovoltaic use.
\end{abstract}

(c) 2012 Elsevier B.V. All rights reserved.

\section{Introduction}

The integration of Photovoltaic (PV) technologies in buildings is a solar active strategy aligned with the current international sustainability and renewable energy criteria for buildings.

In Brazil, a low-latitude country characterized by the high availability and uniformity of solar radiation, the use of PV solar energy is still incipient.

The first BIPV in the country was installed in 1997 at LABSOLAR/UFSC, an academic building in Florianopolis, still in use [1]. Nowadays, there are approximately $20 \mathrm{MW}$ of PV installed, but only $235 \mathrm{~kW}$ of them are grid connected, mostly in research centers and universities, for educational and researching purposes [2]. The main barrier for the use of PV in buildings is identified as the actual price of PV modules and components, estimated, for a conventional system, of about $3500 € / \mathrm{kWp}$ [3]. Although Brazil is an exporter of industrial quality silicon, the national industry does not produce all the required components, leading to the fact that almost all of them have to be imported from Europe and the U.S.A. It is also important to consider the lack of awareness of this technology among general public and even professionals in the construction sector.

\footnotetext{
* Corresponding author.

E-mail addresses: joara.cronemberger@upm.es (J. Cronemberger), estefania.cmartin@upm.es (E. Caamaño-Martín), sergio.vega@upm.es (S.V. Sánchez).
}

However, there are several recent initiatives which give some hints that lead to think that there will be a change in this situation shortly. For instance, a proposal for the implementation of a residential feed-in tariff plan based on this type of energy [4] is currently being studied. Brazil has also been considered one of the most important countries on the planet's Sunbelt, according to PV estimations for 2020 [5]. Martins et al. have already identified the use of grid connected BIPV systems in Brazil as the highest potential for the use of this natural resource, together with standalone systems [6]. Jardim et al. have written about the advantages of the distributed nature of PV electricity generation for the complex national electric grid [7].

The most important goal in the definition of a solar PV system is to maximize the use of the available solar irradiance, followed by preventing or reducing the losses due to shading to a minimum, cell temperature, dispersion, dirtiness, and wiring and DC/AC conversion. This key issue is defined by the geographical location, the orientation and tilt angles of the PV generator.

For Building-integrated Photovoltaics (BIPV) in urban areas, this aspect acquires specific nuances. Mainly because when integrating PV modules in buildings, the best tilt and orientation angles are not always possible, as there are many other factors architects and engineers have to harmonize - lot conditions, urban regulations, form and function of the building, constructive systems or materials available. Other authors have identified before [8] the importance of information on available irradiation on tilted planes as of special interest for architects and engineers during the decision process. This data will not only define the PV system per se, but also play an 
important role during the architectural preliminary design phase of a building.

In countries where this technology is already a daily reality, such as Germany, Japan or Spain, the recommendations and basic criteria to minimize losses due to the PV generator's orientation and tilt angles are widespread [9-16].

A deeper analysis is needed to adapt those criteria to a country which is taking the first step in this area, to avoid false assumptions and practices that may lead to discouragements and eventually become obstacles to PV deployment. Because, if an optimal situation is not achieved, which may happen in many cases, there are still a wide range of possible combinations that may enable producing a worthy amount of solar electric energy, and BIPV can be considered.

This paper analyzes the possibilities of harnessing the potential solar irradiation by different surfaces in Brazilian cities (located at latitudes between $0^{\circ}$ and $30^{\circ} \mathrm{S}$ ), with the aim of providing tools to assess the suitability of the building envelopes for integrating PV technologies.

\section{Literature review}

Many references can be found in literature about the optimal tilt for fixed PV generators that give different recommendations. Some authors recommend inclining the surface with the same angle as the local latitude [9-11], others to incline it approximately $8^{\circ}$ deviated from latitude [12] or to use the relation $\beta_{\text {opt }}=3.7+0.96|\Phi|$ [13].

Furthermore, it is possible to find advice in technical manuals instructing that the optimal position is found for a tilt equal to the local latitude [14], $10^{\circ}$ below the local latitude [15] or even $20^{\circ}$ below the local latitude [16].

Numerous other studies have been made to better accurate the impact of tilt angle and orientation in PV performance according to different latitudes and climates [17-19] some of them also taking different variables into consideration, like marketing energy prices [20] or seasonal solar irradiation characteristics [21], most of them for North oriented latitudes.

Regarding the available annual global irradiation in BIPV systems, it is possible to find references in technical literature which consider as optimal to use more than $90 \%$ of the maximum value for an optimally-inclined-oriented surface, and good between $80 \%$ and $90 \%$ [22].

For German locations, there are references that consider an acceptable circumstance placing PV generators on East and West façades [23], even though for those latitudes, the maximum irradiation expected is situated around 55\%. Whereas the annual global radiation in the country varies between $900 \mathrm{kWh} / \mathrm{m}^{2}$ and $1250 \mathrm{kWh} / \mathrm{m}^{2}$, a façade that annually receives about $600 \mathrm{kWh} / \mathrm{m}^{2}$ is recognized as acceptable for certain circumstances.

In 2006 a new Technical Building Code was published in Spain, which is a pioneering norm which fosters the implementation of energy efficiency measures and renewable energy in buildings, among them, the integration of Photovoltaic technology. This official document considers that "there is architectural integration when the modules fulfill a double function - energetically and architecturally - and also substitute conventional building components or are constituent elements of the architectonical composition" [15]. It states that for the cases of BIPV systems, besides being placed in parallel to the main axis of the building, losses due to orientation and tilt angle shall not be higher than $40 \%$. That means that $60 \%$ use of the available global irradiation is considered a minimum acceptable threshold. Considering that the annual global irradiation in Spain varies between $1.200 \mathrm{kWh} / \mathrm{m}^{2}$ and $1.850 \mathrm{kWh} / \mathrm{m}^{2}$, the values obtained for $60 \%$ will vary from $720 \mathrm{kWh} / \mathrm{m}^{2}$ to $1.110 \mathrm{kWh} / \mathrm{m}^{2}$.

All these recommendations are confirmed for the latitudes which they come from. But, what happens when we want a first approach in a location at low latitudes, specifically in Brazil?

\section{Methodology}

To answer that question we wanted to analyze the amount of solar irradiation for different tilt angles and orientations in Brazil.

The first step of this analysis was to identify the optimal tilt angle of fixed surfaces in 78 Brazilian cities located between $30^{\circ} \mathrm{S}$ and $0^{\circ} \mathrm{S}$ and relate them to the local latitude. The optimal tilt angle $\left(\beta_{\text {opt }}\right)$ is defined for this purpose as the tilt angle of a fixed surface, measured from the horizontal plane, which receives the maximum annual amount of solar irradiation.

Therefore, the annual irradiation received on a surface facing North with a tilt angle equal to the latitude has been calculated using widely validated solar radiation models. Subsequently, the tilt angle has been changed to values higher and lower than latitude angle, with a precision of $1^{\circ}$, and maximum irradiation were recalculated, in order to verify the deviation.

In a second step, global solar irradiation charts have been plotted for 7 cities selected among the 78 previously mentioned, each one located within approximately $5^{\circ}$ of latitude.

\subsection{Calculation of solar irradiation}

The global solar irradiation on arbitrarily oriented and tilted surfaces, $G_{\mathrm{dm}}(\beta, \alpha)$ has been calculated using as input the monthly daily average irradiation data on horizontal surfaces, $G_{\mathrm{dm}}(0)$, published by the World Radiation Data Center [24].

To this aim, first of all the different component of initial data has been calculated, based on the original idea of Liu and Jordan [25]. The correlation proposed by Collares-Pereira and Rabl [26] for the correlation between the Clearness Index $K_{\mathrm{Tm}}$ and the Diffuse Fraction $K_{\mathrm{Dm}}$ has been used:

$K_{\mathrm{Dm}}=1-1.13 K_{\mathrm{Tm}}$

where:

$K_{\mathrm{Tm}}=\frac{G_{\mathrm{dm}}(0)}{B 0_{\mathrm{dm}}(0)}$

$K_{\mathrm{dm}}=\frac{D_{\mathrm{dm}}(0)}{G_{\mathrm{dm}}(0)}$

Being $B 0_{\mathrm{dm}}(0)$ the daily mean extraterrestrial beam irradiation on a horizontal surface, $D_{\mathrm{dm}}(0)$ the diffuse fraction of the horizontal radiation and $G_{\mathrm{dm}}(0)$ the monthly daily average irradiation data on a horizontal surface.

After calculating the different component of initial data, hourly values of global and diffuse irradiations, $G_{\mathrm{h}}(0)$ and $D_{\mathrm{h}}(0)$ have been estimated using the following expressions proposed by Liu and Jordan [27]:

$r_{\mathrm{d}}=\frac{D_{\mathrm{h}}(0)}{D_{\mathrm{d}}(0)}$

$r_{\mathrm{g}}=\frac{G_{\mathrm{h}}(0)}{G_{\mathrm{d}}(0)}$

Parameters $r_{\mathrm{d}}$ and $r_{\mathrm{g}}$ were calculated as follows:

$r_{\mathrm{d}}=\frac{\pi}{T} \cdot\left(\frac{\cos \omega-\cos \omega_{\mathrm{s}}}{\sin \omega_{\mathrm{s}}-\omega_{\mathrm{s}} \cdot \cos \omega_{\mathrm{s}}}\right)$

$r_{\mathrm{g}}=r_{\mathrm{d}}\left(a+b \cdot \cos \omega_{\mathrm{s}}\right)$

$a=0.409+0.5016 \cdot \sin \left(\omega_{\mathrm{s}}-1.047\right)$ 
Table 1

Coefficients for Pérez model.

\begin{tabular}{|c|c|c|c|c|c|c|}
\hline Range $\varepsilon$ & $k_{31}$ & $k_{32}$ & $k_{33}$ & $k_{41}$ & $k_{42}$ & $k_{43}$ \\
\hline $1-1.056$ & -0.042 & 0.55 & -0.044 & -0.12 & 0.138 & -0.034 \\
\hline $1.056-1.253$ & 0.261 & 0.559 & -0.243 & -0.019 & 0.083 & -0.081 \\
\hline $1.253-1.586$ & 0.481 & 0.46 & -0.354 & 0.077 & -0.006 & -0.116 \\
\hline $1.586-2.134$ & 0.825 & 0.187 & -0.532 & 0.172 & -0.05 & -0.151 \\
\hline $2.134-3.23$ & 1.102 & -0.299 & -0.586 & 0.35 & -0.398 & -0.171 \\
\hline $3.23-5.98$ & 1.226 & -0.451 & -0.617 & 0.444 & -0.949 & -0.073 \\
\hline $5.98-10.08$ & 1.367 & -0.838 & -0.655 & 0.431 & -1.75 & 0.094 \\
\hline 10.08 & 0.978 & -0.812 & -0.393 & 0.335 & -2.16 & 0.186 \\
\hline
\end{tabular}

$b=0.6609-0.4767 \cdot \sin \left(\omega_{\mathrm{s}}-1.047\right)$

where $\omega$ and $\omega_{\mathrm{s}}$ are expressed in radians and $T$ is the length of the day in hours $T=24$. Once the hourly global and diffuse irradiation values are known, respectively $G_{\mathrm{h}}(0)$ and $D_{\mathrm{h}}(0)$, the difference between them is the hourly beam irradiation $B_{\mathrm{h}}(0)$ :

$B_{\mathrm{h}}(0)=G_{\mathrm{h}}(0)-D_{\mathrm{h}}(0)$

To calculate the hourly average irradiation on an arbitrarily oriented tilted surface, $G_{\mathrm{h}}(\beta, \alpha)$ its main components have been individually divided:

$G_{\mathrm{h}}(\beta, \alpha)=B_{\mathrm{h}}(\beta, \alpha)+D_{\mathrm{h}}(\beta, \alpha)-R_{\mathrm{h}}(\beta, \alpha)$

Being $B_{\mathrm{h}}, D_{\mathrm{h}}$ and $R_{\mathrm{h}}$ respectively the hourly beam irradiation, diffuse irradiation and reflected or albedo irradiation.To calculate the beam irradiation, the law of cosines has been applied:

$B_{\mathrm{h}}(\beta, \alpha)=\left(\frac{B_{\mathrm{h}}(0)}{\cos \theta_{\mathrm{zs}}}\right) \cdot \max \left(0, \cos \theta_{\mathrm{s}}\right)$

where $\theta_{\mathrm{zs}}$ is the Sun's zenith angle and $\theta_{\mathrm{s}}$ is the incidence angle of the sun's rays for the average value of the hour studied.

For the diffuse component, the widely used model proposed by Pérez [27] has been considered. It differentiates three regions in the sky - a circumsolar disc with a determined angular spread $\xi_{1}$, a horizontal band with another angular spread, $\xi_{2}$, and the rest of the sky hemisphere, which is supposed to behave as an isotropic radiation emitter. The model identifies two different components, one coming from the circumsolar region $D_{\mathrm{h}}^{\mathrm{C}}(\beta, \alpha)$ and another from the rest of the celestial hemisphere $D_{\mathrm{h}}^{1}$, resulting in:

$D_{\mathrm{h}}^{\mathrm{C}}(\beta, \alpha)=D_{\mathrm{h}}(0)\left(\frac{k_{3} \cos \theta_{\mathrm{s}}}{\cos \theta_{\mathrm{zs}}}\right)$

$D_{\mathrm{h}}^{1}(\beta, \alpha)=D_{\mathrm{h}}(0)\left(\frac{1+\cos \beta\left(1-k_{3}\right)}{2 k_{4 \sin } \beta}\right)$

where $D_{\mathrm{h}}^{1}(\beta, \alpha)$ is the isotropic diffuse irradiation, and $k_{3}$ and $k_{4}$ are adimensional parameters given by:

$k_{3}=k_{31}(\varepsilon)+k_{32}(\varepsilon) \Delta+k_{33}(\varepsilon) \theta_{\mathrm{zs}}$

$k_{4}=k_{41}(\varepsilon)+k_{42}(\varepsilon) \Delta+k_{43}(\varepsilon) \theta_{\mathrm{zs}}$

where $\theta_{\mathrm{zs}}$ is expressed in radians and:

$\varepsilon=D_{\mathrm{h}}(0)+\left(\frac{B_{\mathrm{h}}(0) / \cos \theta_{\mathrm{zs}}}{D_{\mathrm{h}}(0)}\right)$

$\Delta=D_{\mathrm{h}}(0) \frac{\mathrm{AM}}{B_{\mathrm{sc}}}$

$\mathrm{AM}=\frac{1}{\cos \theta_{\mathrm{zs}}}$

The values of the coefficients $k_{31}-k_{32}$ and $k_{41}-k_{43}$ for the implementation of the Pérez model are presented in Table 1.

Finally, to calculate the albedo component, the ground was supposed to behave as an infinite and horizontal surface which isotropically reflects the radiation received, expressed by the relation:

$R_{\mathrm{h}}(\beta)=G_{\mathrm{h}}(0) \rho \frac{(1-\cos \beta)}{2}$

where $\rho$ is the ground reflexivity, supposed $\rho=0.2$ for all cases.

Once the hourly values of global irradiation data have been obtained, the daily average global irradiation $G_{\mathrm{dm}}(\beta, \alpha)$ has been finally calculated as:

$G_{\mathrm{dm}}(\beta, \alpha)=\sum_{h=1}^{24} G_{\mathrm{dm}}(\beta, \alpha)$

\subsection{Irradiation losses due to tilt and orientation charts}

To show graphically the irradiation losses due to tilt and orientation, charts of the available solar resource were drawn for 7 cities, located at approximately every $5^{\circ}$ of latitude: Belém $\left(\phi=1.4^{\circ} \mathrm{S}\right)$, Teresina $\left(\phi=5^{\circ} S\right)$, Aracajú $\left(\phi=10.9^{\circ} S\right)$, Brasília $\left(\phi=15.7^{\circ} \mathrm{S}\right)$, Belo Horizonte $\left(\phi=19.9^{\circ} S\right)$, Curitiba $\left(\phi=25.3^{\circ} S\right)$ and Porto Alegre $\left(\phi=30^{\circ}\right.$ S) (Fig. 1).

Hence, the annual irradiation received by a fixed surface with different tilts and orientations ( $\beta$ and $\alpha$, respectively) were calculated, for each one of the 7 sites selected. In order to have enough data to allow an accurate chart, the following scheme was conceived: for a fixed North orientation, the tilt angle was positioned from completely horizontal $\left(0^{\circ}\right)$ to completely vertical $\left(90^{\circ}\right)$, and calculated every $5^{\circ}$. The azimuth was then displaced $5^{\circ}$ and the

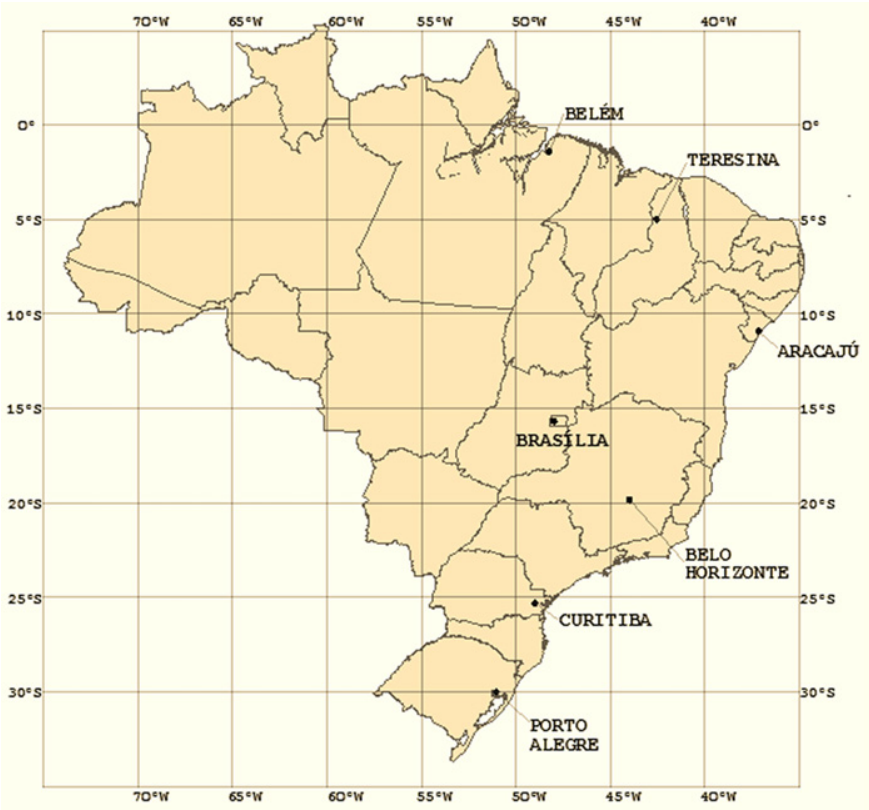

Fig. 1. Location of the 7 selected cities in Brazil. 


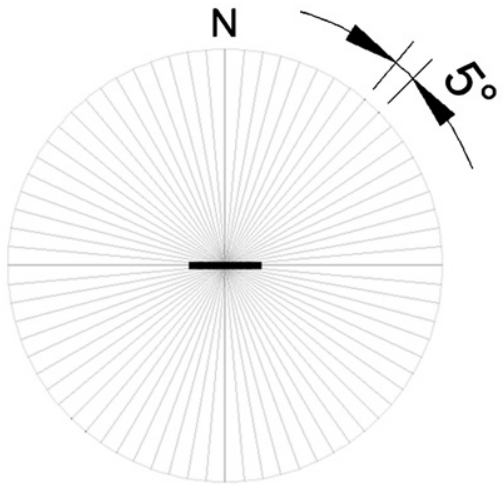

Azimuth variation

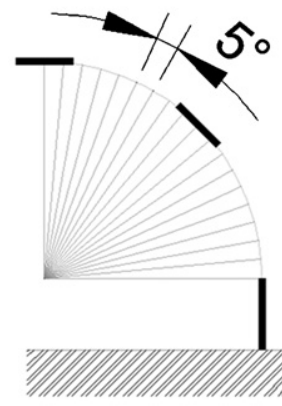

Tilt variation
Fig. 2. Surfaces calculated scheme.

irradiation data calculated again to the different tilts, and then successively each $5^{\circ}$, till the complete sky had been covered (Fig. 2). Therefore, the irradiation curves shown in the charts are defined by 1.368 reference points.

The data were applied to plot a polar contour graph using the graphic software OriginPro 8.5. Each one of the graphs was created directly from data organized in 3 axis as theta (azimuth), radius (tilt angle) and zeta (irradiation), by triangulation.

\section{Results and discussion}

\subsection{Optimal tilt}

It was found from calculations that, for the 78 cities studied, only in 8 of them the optimal tilt is equal to the latitude. In the other 70 cities, the optimal angle varies between $1.5^{\circ}$ and $9.3^{\circ}$ above the latitude. None has presented the optimal tilt angle below the latitude angle value.

The results of the maximum annual global irradiation for the 78 Brazilian cities, calculated using the models explained in Section 3.2, are shown in Table 2 . All surfaces are optimally oriented $\left(\alpha=180^{\circ}\right)$.

In order to see clearly the relation between latitude versus optimal tilt angle in the 78 cities, a Scatter chart was plotted (Fig. 3). In the $Y$-axis is represented the tilt angle $\beta$ and in the $X$-axis the latitude $\phi$. Dot points represent the relation $\beta=\phi$, and dot stars, the relation $\left(\beta_{\mathrm{opt}}\right)$ and $\phi$, according to the data shown in Table 2 .

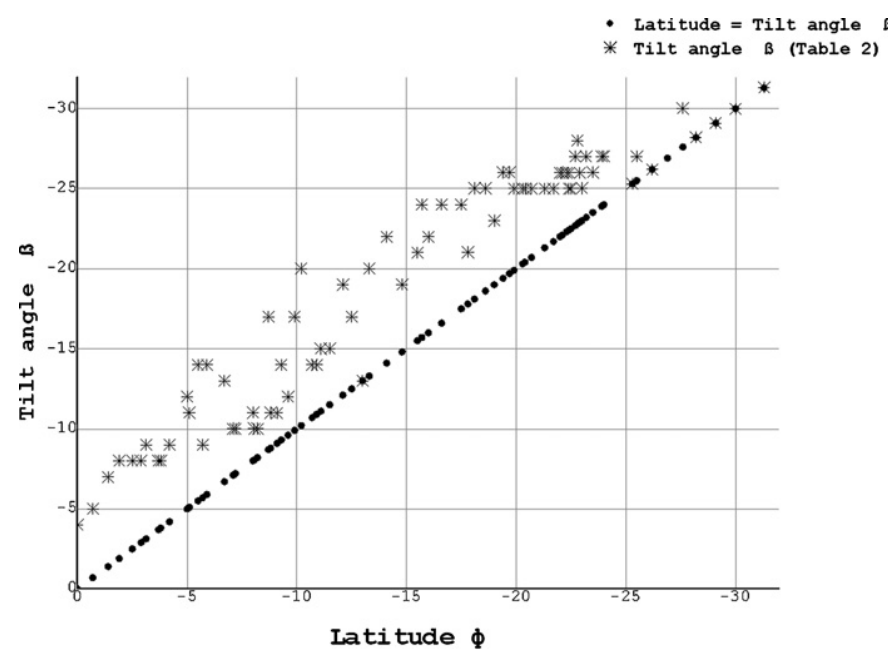

Fig. 3. Relation optimal tilt angle $\beta_{\text {opt }} \times$ latitude $\Phi$.

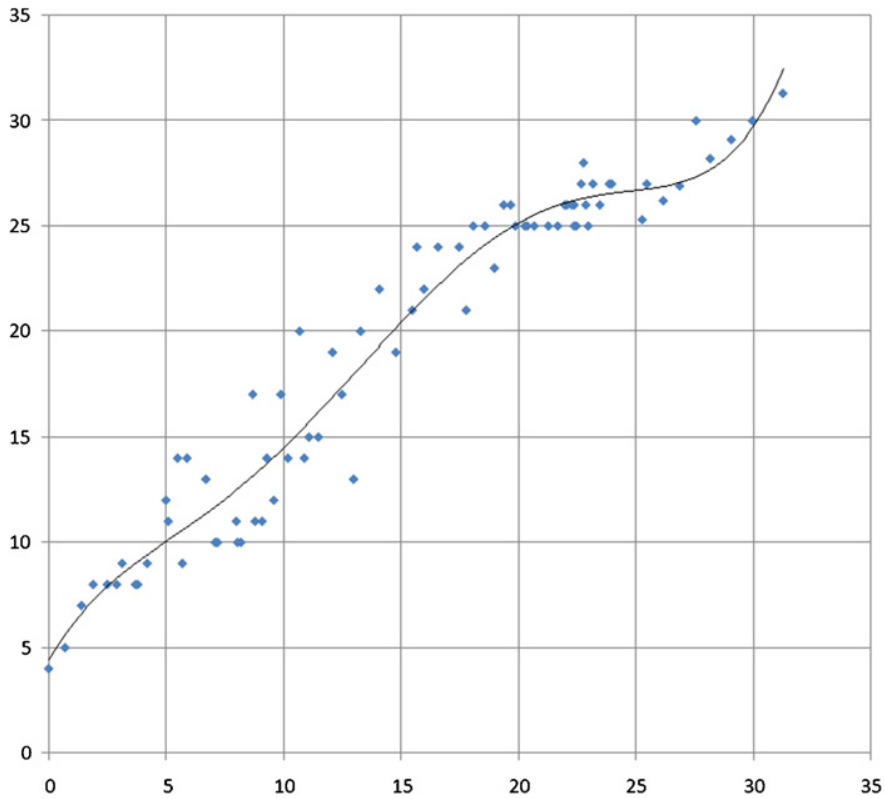

Fig. 4. Polynomial equation for $\beta_{\text {opt }} \times$ latitude $\Phi$.

Calculation results show that between latitudes $0^{\circ}$ and $5^{\circ}$, the optimal tilt is higher than the latitude, the average increase being $5.2^{\circ}$. Between $5.1^{\circ}$ and $19.9^{\circ}$ however, the increase varies between $0^{\circ}$ and a maximum of $9.3^{\circ}$, with an average of $5.1^{\circ}$. From $20.3^{\circ}$ to $31.0^{\circ}$, the optimal tilt is predominantly up to a maximum of $5^{\circ}$ above the latitude, with an average of $2.6^{\circ}$.

In consequence, the recommendations mentioned in [9-11,14] are suitable for only 8 of the 78 cities. To use the ones in $[12,13,15,16]$ would not give the best irradiation result for the 70 remaining locations.

Fig. 4 shows a graphical representation of $\left(\beta_{\text {opt }}\right)$ versus local latitude $\phi$, as well as an analytical modeling of the result. It can be seen how the relation between the latitude and the optimal tilt can be described by a sixth degree polynomial function curve, which correspondent determination coefficient being $R^{2}=0.951$, indicative of its goodness:

$$
\begin{aligned}
\beta_{\mathrm{opt}}= & 2 e-05|\Phi|^{5}-0.001|\Phi|^{4}+0.028|\Phi|^{3}-0.274|\Phi|^{2} \\
& +1.927|\Phi|+4.413
\end{aligned}
$$

It is worth mentioning a clear tendency observed in the data of Table 2 and Fig. 3, that as closer is the location from the Equator, the higher is the value for $\beta_{\text {opt }}$ above the latitude. Indeed, from $\phi \geq 25^{\circ}$, the values for $\beta_{\text {opt }}$ are more likely the same of latitude's, as it can be seen in Fig. 4. This is due to the fact that, in low latitude cities, although due to the sun trajectories (in the northern and southern hemispheres) the maximum solar gain would be theoretically obtained when the surface is tilted an angle given by the local latitude, the solar radiation models show that, due to local climatic conditions (solar resource available, diffuse content of solar radiation, etc.), the maximum solar gain is obtained for a slightly higher tilt angle. It is precisely for locations with latitude higher than $25^{\circ}$ when this tendency changes.

This can be seen clearly in Fig. 4, where the fitting curve resulting from applying a polynomial regression (22) to individual data points $\left(\beta_{\text {opt }}\right.$ versus local latitude $\left.\phi\right)$. Due to the change of tendency mentioned previously, observed at $\phi=25^{\circ}$, the fitting curve changes consequently at such latitude. 
Table 2

Maximum annual irradiation and optimal angle.

\begin{tabular}{|c|c|c|c|c|}
\hline A & B & $\mathrm{C}$ & $\mathrm{D}$ & $E$ \\
\hline City & $\Phi$ & $G_{\mathrm{a}}\left(\beta=\Phi, \alpha=180^{\circ}\right) \mathrm{kWh} / \mathrm{m}^{2} \mathrm{y}$ & $\beta_{\text {opt }}$ & $G_{\mathrm{a}}\left(\beta=\beta_{\mathrm{opt}}, \alpha=180^{\circ}\right) \mathrm{kWh} / \mathrm{m}^{2} \mathrm{y}$ \\
\hline Bagé & -31.3 & 1797 & 31.3 & 1797 \\
\hline Porto Alegre & -30 & 1810 & 30 & 1810 \\
\hline Caxias do Sul & -29.1 & 1736 & 29.1 & 1736 \\
\hline Passo Fundo & -28.2 & 1870 & 28.2 & 1870 \\
\hline Florianópolis & -27.6 & 1721 & 30 & 1722 \\
\hline Blumenau & -26.9 & 1564 & 26.9 & 1564 \\
\hline Sao Francisco do Sul & -26.2 & 1637 & 26.2 & 1637 \\
\hline Foz de Iguaçú & -25.5 & 1841 & 27 & 1842 \\
\hline Curitiba & -25.3 & 1460 & 25.3 & 1460 \\
\hline Campo Mourao & -24 & 1880 & 27 & 1882 \\
\hline Santos & -23.9 & 1633 & 27 & 1634 \\
\hline Sao Paulo & -23.5 & 1559 & 26 & 1561 \\
\hline Sao José dos Campos & -23.2 & 1769 & 27 & 1772 \\
\hline Taubaté & -23 & 1768 & 25 & 1771 \\
\hline Rio de Janeiro & -22.9 & 1833 & 26 & 1835 \\
\hline Campinas & -22.8 & 1951 & 28 & 1957 \\
\hline Piracicaba & -22.7 & 1905 & 27 & 1910 \\
\hline Ponta Porâ & -22.5 & 1882 & 25 & 1884 \\
\hline Resende & -22.4 & 1773 & 26 & 1776 \\
\hline Volta Redonda & -22.4 & 1632 & 25 & 1634 \\
\hline Macaé & -22.3 & 1913 & 26 & 1917 \\
\hline Presidente Prudente & -22.1 & 1944 & 26 & 1948 \\
\hline Sao Carlos & -22 & 1899 & 26 & 1903 \\
\hline Juiz de Fora & -21.7 & 1644 & 25 & 1646 \\
\hline Cataguases & -21.3 & 1790 & 25 & 1793 \\
\hline Viçosa & -20.7 & 1861 & 25 & 1866 \\
\hline Campo Grande & -20.4 & 1928 & 25 & 1933 \\
\hline Vitória & -20.3 & 1902 & 25 & 1906 \\
\hline Belo horizonte & -19.9 & 1699 & 25 & 1705 \\
\hline Uberaba & -19.7 & 2054 & 26 & 2064 \\
\hline Sete Lagoas & -19.4 & 2058 & 26 & 2069 \\
\hline Corumbá & -19 & 1970 & 23 & 1975 \\
\hline Patos de Minas & -18.6 & 1980 & 25 & 1991 \\
\hline Catalao & -18.1 & 1960 & 25 & 1972 \\
\hline Teófilo Otoni & -17.8 & 1783 & 21 & 1786 \\
\hline Paracatu & -17.5 & 1920 & 24 & 1930 \\
\hline Goiânia & -16.6 & 1939 & 24 & 1953 \\
\hline Cáceres & -16 & 1822 & 22 & 1831 \\
\hline Brasília & -15.7 & 1907 & 24 & 1926 \\
\hline Cuiabá & -15.5 & 1944 & 21 & 1951 \\
\hline Vitória da Conquista & -14.8 & 1768 & 19 & 1773 \\
\hline Posse & -14.1 & 1911 & 22 & 1925 \\
\hline Correntina & -13.3 & 1962 & 20 & 1972 \\
\hline Salvador & -13 & 1956 & 13 & 1956 \\
\hline Lençóis & -12.5 & 1714 & 17 & 1718 \\
\hline Barreiras & -12.1 & 2022 & 19 & 2036 \\
\hline Morro do Chapéu & -11.5 & 1686 & 15 & 1689 \\
\hline Jacobina & -11.1 & 1803 & 15 & 1806 \\
\hline Aracajú & -10.9 & 2031 & 14 & 2034 \\
\hline Palmas & -10.7 & 1971 & 20 & 1993 \\
\hline Propriá & -10.2 & 1890 & 14 & 1891 \\
\hline Rio Branco & -9.9 & 1667 & 17 & 1676 \\
\hline Maceió & -9.6 & 1980 & 12 & 1981 \\
\hline Petrolina & -9.3 & 1987 & 14 & 1992 \\
\hline Porto das Pedras & -9.1 & 1944 & 11 & 1945 \\
\hline Garanhuns & -8.8 & 1906 & 11 & 1907 \\
\hline Porto velho & -8.7 & 1697 & 17 & 1710 \\
\hline Caruaru & -8.2 & 1871 & 10 & 1872 \\
\hline Recife & -8.05 & 2092 & 10 & 2093 \\
\hline Olinda & -8 & 2016 & 11 & 2019 \\
\hline Campina Grande & -7.2 & 1865 & 10 & 1866 \\
\hline Joao Pessoa & -7.1 & 2016 & 10 & 2018 \\
\hline Floriano & -6.7 & 1911 & 13 & 1919 \\
\hline Colinas & -5.9 & 1804 & 14 & 1820 \\
\hline Natal & -5.7 & 2071 & 9 & 2073 \\
\hline Imperatriz & -5.5 & 1802 & 14 & 1818 \\
\hline Crateús & -5.1 & 1981 & 11 & 1988 \\
\hline Teresina & -5 & 2015 & 12 & 2027 \\
\hline Guaramiranga & -4.2 & 1714 & 9 & 1720 \\
\hline Fernando de Noronha & -3.8 & 2019 & 8 & 2023 \\
\hline Fortaleza & -3.7 & 2030 & 8 & 2035 \\
\hline Manaus & -3.13 & 1797 & 9 & 1805 \\
\hline Parnaíba & -2.9 & 2073 & 8 & 2079 \\
\hline Sao Luiz & -2.5 & 1791 & 8 & 1798 \\
\hline Óbidos & -1.9 & 1875 & 8 & 1885 \\
\hline Belém & -1.4 & 1838 & 7 & 1847 \\
\hline Soure & -0.7 & 1907 & 5 & 1912 \\
\hline Macapá & 0 & 1834 & 4 & 1838 \\
\hline
\end{tabular}

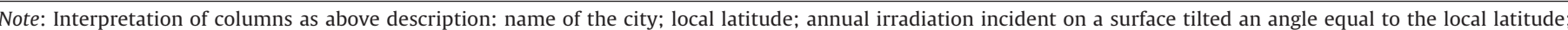
optimal tilt; maximum annual irradiation, as obtained from using the methodology described in Section 3.1. 
Table 3

Annual output for the available irradiation.

\begin{tabular}{|c|c|c|c|c|c|c|}
\hline City & $\begin{array}{l}\text { Maximum Irradiation } \\
\left(\mathrm{KWh} / \mathrm{m}^{2} \mathrm{y}\right)\end{array}$ & Latitude $(\Phi)$ & Surface position $(\beta)$ & North (\%) & East/West (\%) & South (\%) \\
\hline Porto Alegre/RS & 1.810 & $-30.0^{\circ}$ & $\begin{array}{l}\text { Roofs } \\
\text { Façades }\end{array}$ & $\begin{array}{l}89.1-100 \\
60.3-98.7\end{array}$ & $\begin{array}{l}85.5-89.3 \\
54.5-81.9\end{array}$ & $\begin{array}{l}66.6-89.0 \\
25.9-55.9\end{array}$ \\
\hline Curitiba/PR & 1.460 & $-25.3^{\circ}$ & $\begin{array}{l}\text { Roofs } \\
\text { Façades }\end{array}$ & $\begin{array}{l}92.3-100 \\
57.5-97.6\end{array}$ & $\begin{array}{l}87.5-92.5 \\
53.3-83.4\end{array}$ & $\begin{array}{l}71.0-92.3 \\
28.6-61.2\end{array}$ \\
\hline Belo Horizonte/MG & 1.705 & $-19.9^{\circ}$ & $\begin{array}{l}\text { Roofs } \\
\text { Façades }\end{array}$ & $\begin{array}{l}92.1-100 \\
56.3-97.4\end{array}$ & $\begin{array}{l}87.6-92.4 \\
55.3-83.5\end{array}$ & $\begin{array}{l}70.7-92.1 \\
27.0-60.6\end{array}$ \\
\hline Brasília/DF & 1.926 & $-15.7^{\circ}$ & $\begin{array}{l}\text { Roofs } \\
\text { Façades }\end{array}$ & $\begin{array}{l}92.5-100 \\
55.1-97.0\end{array}$ & $\begin{array}{l}88.6-92.9 \\
54.6-84.6\end{array}$ & $\begin{array}{l}71.9-92.5 \\
26.6-61.8\end{array}$ \\
\hline Aracajú/SE & 2.034 & $-10.9^{\circ}$ & $\begin{array}{l}\text { Roofs } \\
\text { Façades }\end{array}$ & $\begin{array}{l}96.8-100 \\
45.6-91.8\end{array}$ & $\begin{array}{l}93.1-97.8 \\
56.3-88.5\end{array}$ & $\begin{array}{l}83.5-97.4 \\
31.9-74.7\end{array}$ \\
\hline Teresina/PI & 2.026 & $-5.0^{\circ}$ & $\begin{array}{l}\text { Roofs } \\
\text { Façades }\end{array}$ & $\begin{array}{l}96.0-100 \\
44.3-90.3\end{array}$ & $\begin{array}{l}93.9-98.6 \\
56.4-89.2\end{array}$ & $\begin{array}{l}85.8-98.3 \\
33.8-77.3\end{array}$ \\
\hline Belém/PA & 1.845 & $-1.4^{\circ}$ & $\begin{array}{l}\text { Roofs } \\
\text { Façades }\end{array}$ & $\begin{array}{l}93.3-100 \\
42.0-87.5\end{array}$ & $\begin{array}{l}94.6-99.7 \\
56.3-89.9\end{array}$ & $\begin{array}{l}89.9-99.4 \\
37.8-82.3\end{array}$ \\
\hline
\end{tabular}

Note: $\operatorname{Roofs}\left(\beta=0^{\circ}-30^{\circ}\right)$; façades $\left(\beta=40^{\circ}-90^{\circ}\right)$.

Nevertheless, Fig. 5 shows that from the results, it is also possible to deduce a simpler mathematical relation, through a linear equation, showing also a good coefficient of determination $R^{2}=0.93$ :

$\beta_{\text {opt }}=0.874|\Phi|+6.062$

In all cases resulting from the application of expression (23), the values of irradiation are very close to the maximum values obtained for the optimal tilt angle; differences found were smaller than $2 \%$ in all locations studied.

\subsection{Irradiation losses considering non-optimal tilt and orientation}

\subsubsection{Solar irradiation on roofs}

In the 7 Brazilian cities studied, as can be observed in Table 3, the available solar resource on roofs $\left(0^{\circ} \leq \beta \leq 30^{\circ} \mathrm{S}\right)$ is always more than $89 \%$ of the maximum value for an optimally-inclined-oriented surface, if they face North. In the cities located between latitudes

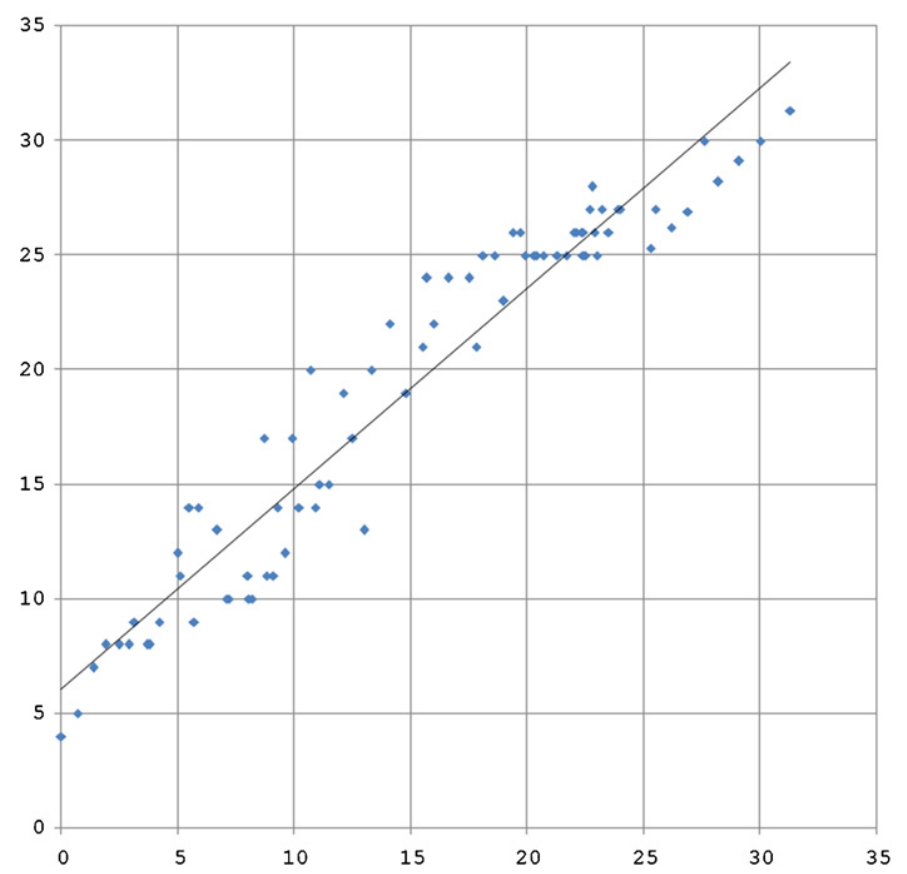

Fig. 5. Linear equation for $\beta_{\text {opt }} \times$ latitude $\Phi$. $15^{\circ}$ and $30^{\circ}$, for East and West orientations, the minimum usage is between $85 \%$ and $89 \%$; between latitudes $1^{\circ}$ and $10^{\circ}$, the minimum usage is higher, always more than 93\%. Considering roofs facing South, the usage, although lower, is also considerable, between $66 \%$ and $99 \%$. See also the annual global irradiation charts: Porto Alegre (Fig. 6), Curitiba (Fig. 7), Belo Horizonte (Fig. 8), Brasília (Fig. 9), Aracajú (Fig. 10), Teresina (Fig. 11) and Belém (Fig. 12).

For example, Fig. 6 shows the global irradiation chart for Porto Alegre $\left(\phi=30^{\circ} \mathrm{S}\right)$. It can be observed that the maximum global irradiation is within a surface inclined to $30^{\circ}$ due North. However, the range for which the combination tilt/orientation is optimal (irradiation usage $\geq 90 \%$ ) is wide: tilts between $2^{\circ}$ and $58^{\circ}$, orientations from NW to NE. Basically, the entire North quadrant presents acceptable combinations, considering $55 \%$ as the minimum usage criteria. For South orientations there are also acceptable combinations, mainly for roof applications.

For Brasilia $\left(\phi=15.7^{\circ} \mathrm{S}\right)$, the maximum annual global irradiation is obtained for a North orientation and a $24^{\circ}$ tilt angle (Fig. 9). Likewise, the range for which the combination tilt/orientation is optimal (irradiation usage $\geq 90 \%$ ) is wide - between $0^{\circ}$ and $53^{\circ}$ tilts, from NW to NE. In the same way as in Porto Alegre, almost the entire North quadrant presents acceptable combinations. For

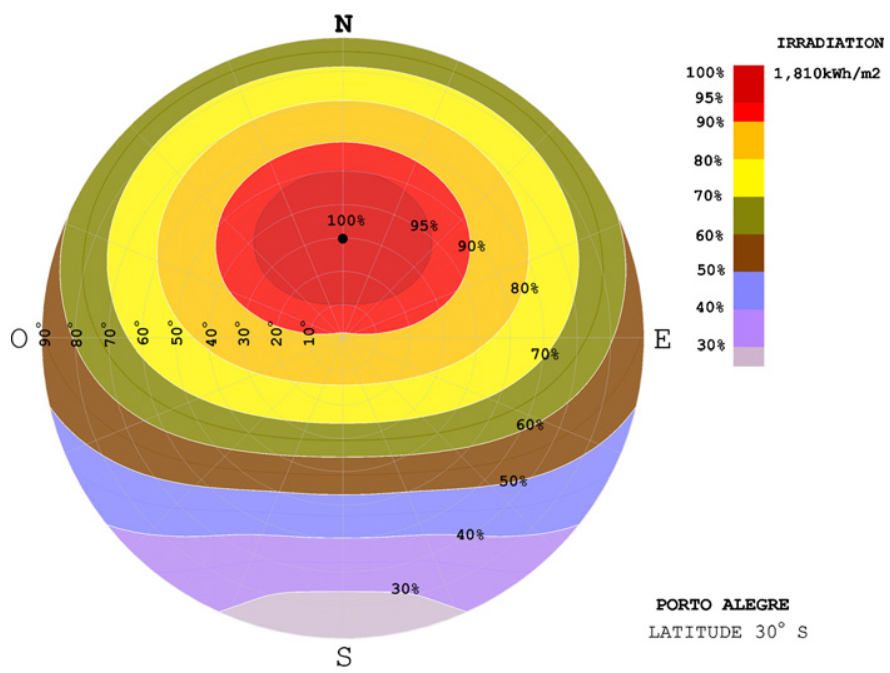

Fig. 6. Porto Alegre: annual global irradiation chart, upon all tilts and azimuths. 


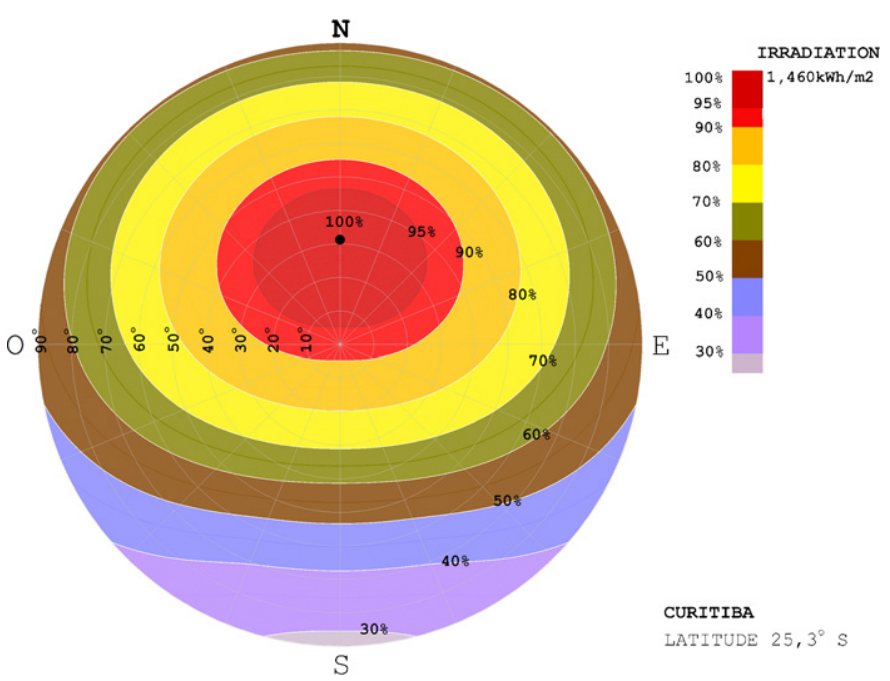

Fig. 7. Curitiba: annual global irradiation chart, upon all tilts and azimuths.

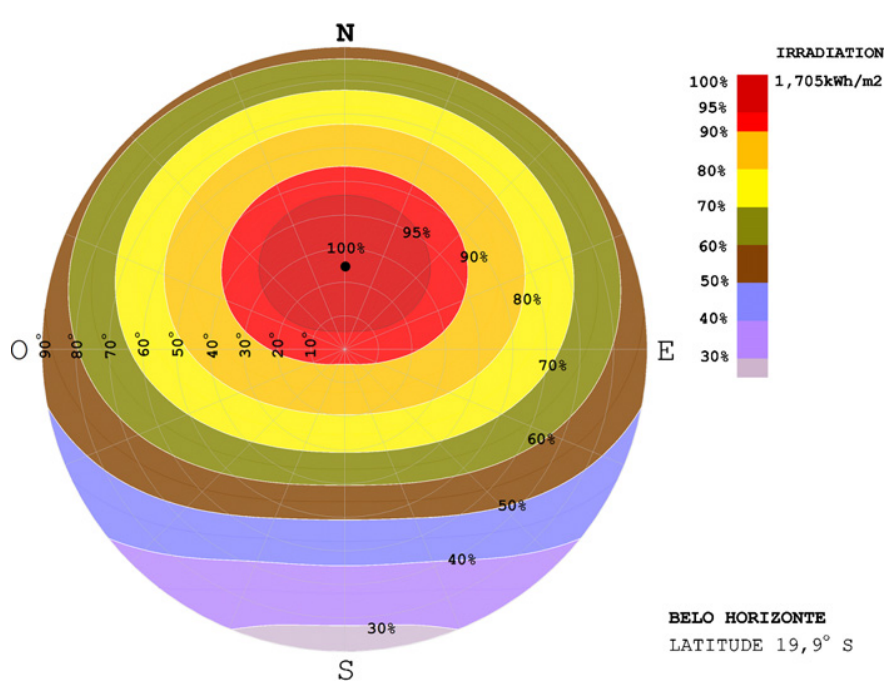

Fig. 8. Belo Horizonte: annual global irradiation chart, upon all tilts and azimuths.

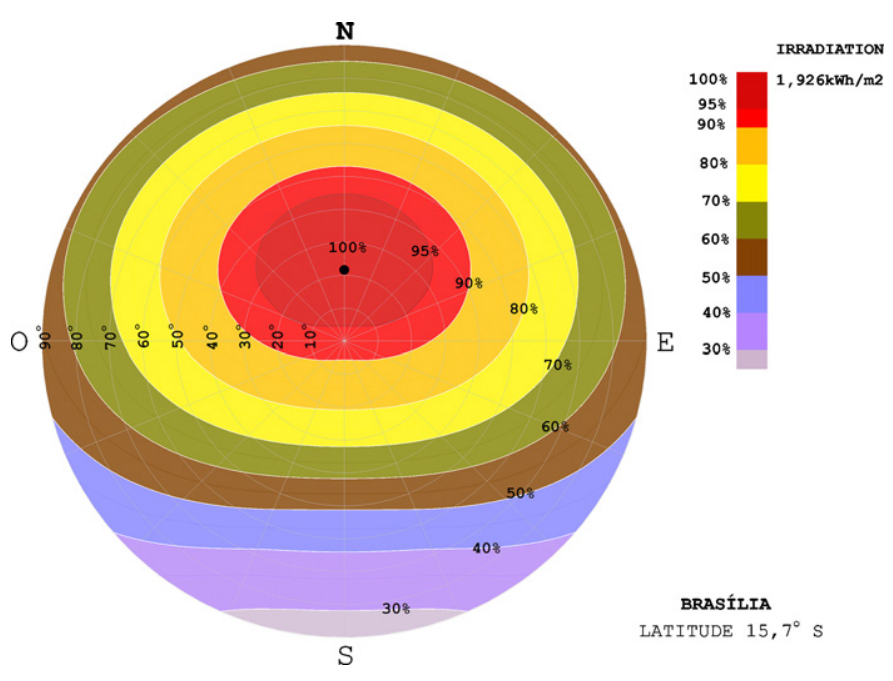

Fig. 9. Brasília: annual global irradiation chart, upon all tilts and azimuths.

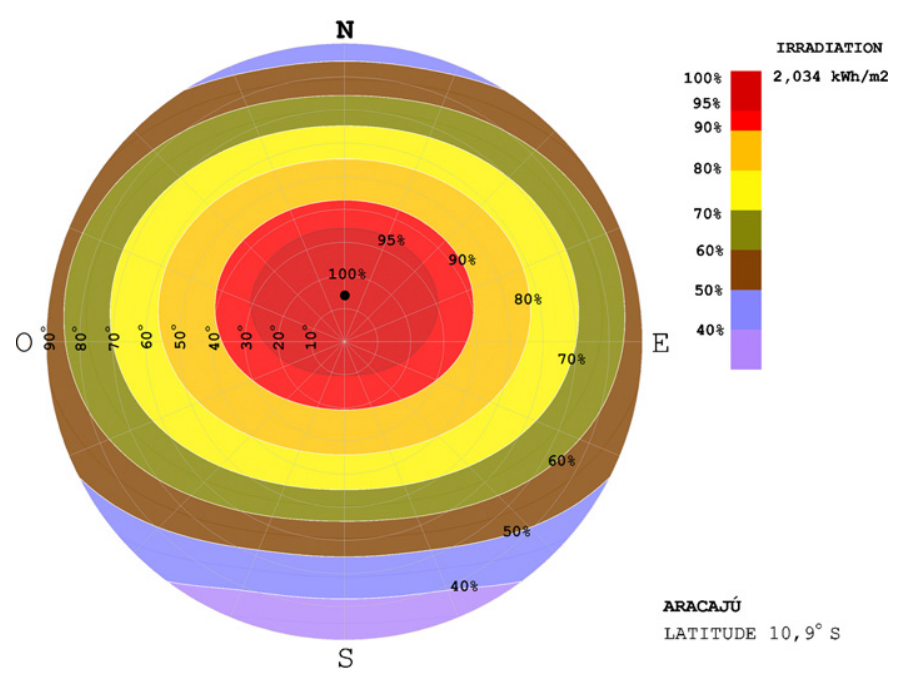

Fig. 10. Aracajú: annual global irradiation chart, upon all tilts and azimuths.

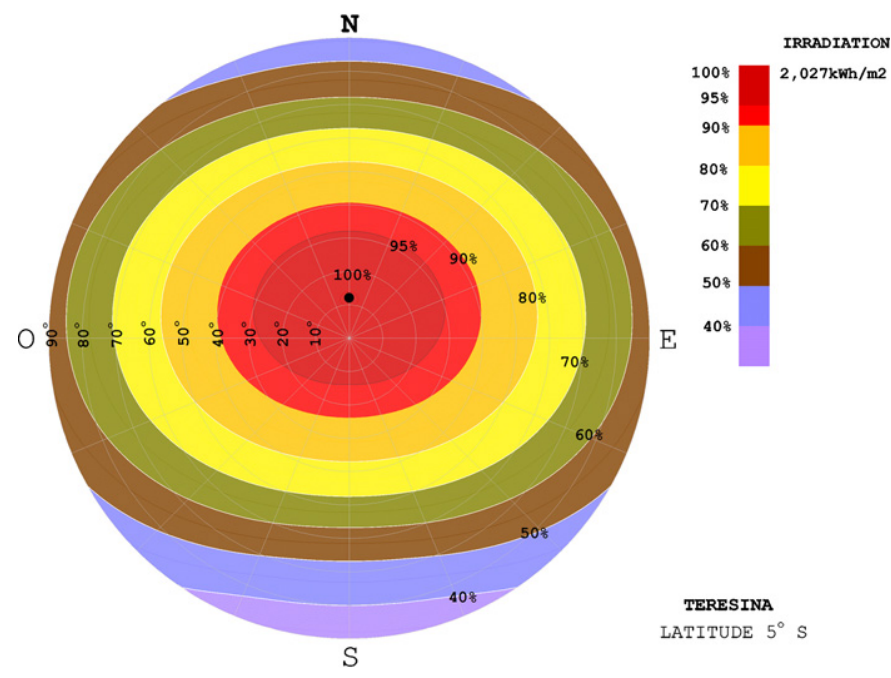

Fig. 11. Teresina: annual global irradiation chart, upon all tilts and azimuths.

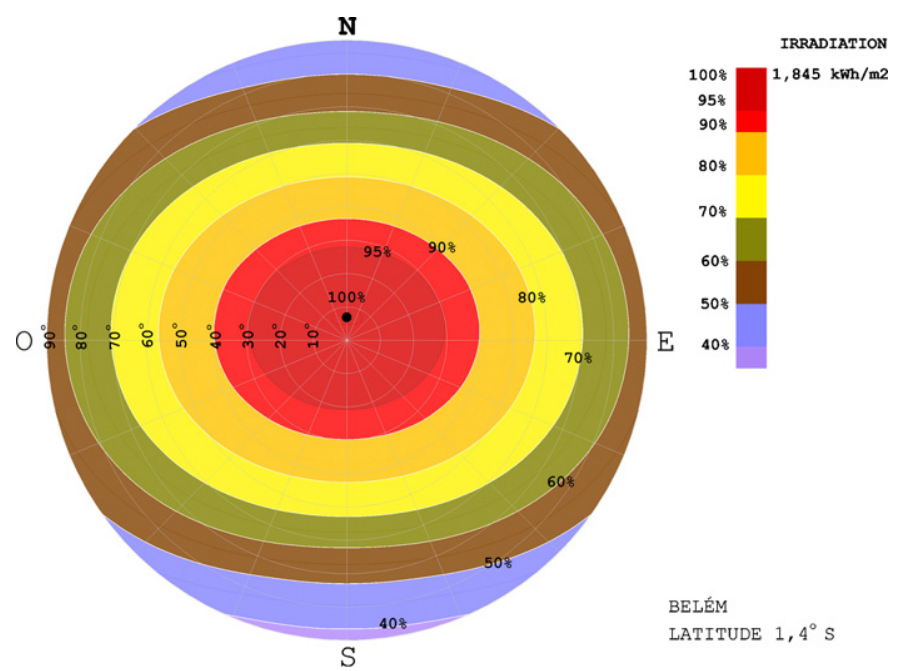

Fig. 12. Belém: annual global irradiation chart, upon all tilts and azimuths. 


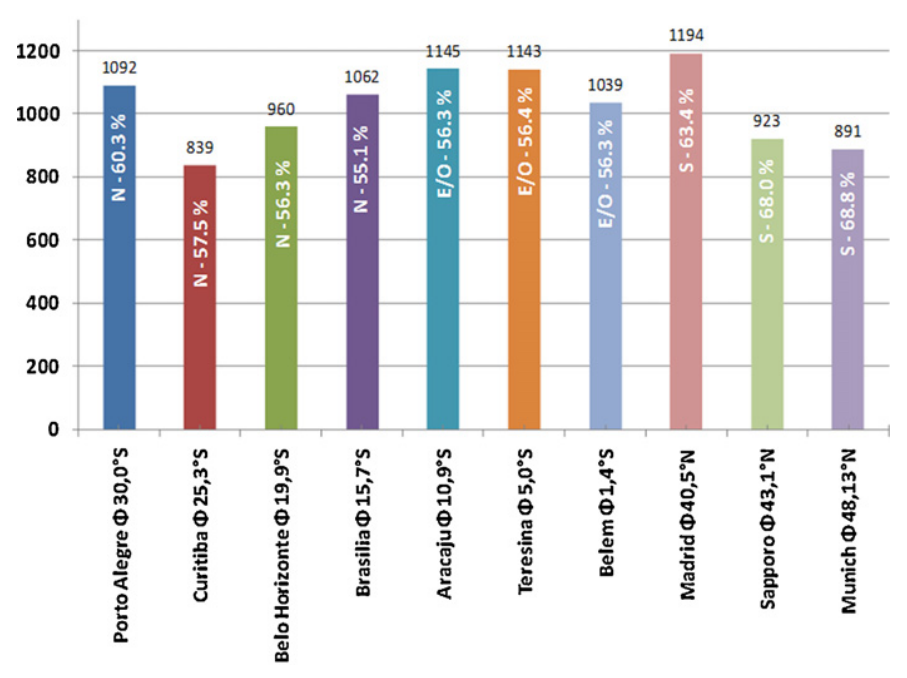

Fig. 13. Comparison of the available solar resource for best façades.

South orientations there are also acceptable combinations for roof applications.

In Belém $\left(\phi=1.4^{\circ} \mathrm{S}\right)$, in North extreme of the country, the maximum annual global irradiation is found at a $7^{\circ}$ tilt angle due North (Fig. 12). The range for which the tilt/orientation combination is optimal is now in the center of the chart, as expected for its proximity to the Earth's equator. Facing any orientation, up to approximately $40^{\circ}$ tilt, a surface would potentially collect more than $90 \%$ of the available global irradiation for that latitude. There are acceptable combinations for almost all orientations, more favorable in the East and West and for higher tilts.

These results indicate that at these latitudes, a wide range of building roof typologies tilted up to $30^{\circ}$, regardless of their orientation, will have good, very good or optimal solar potential yields.

\subsection{Solar irradiation on façades}

As for the use of the solar resource on façades, it has been verified that, for the Brazilian cities simulated, a maximum of $60 \%$ of the available irradiation may be used in vertical façades. As expected, the higher the latitude is, the higher the irradiation received by a façade. Consequently, the highest use rate is found on façades facing North $(60.3 \%)$ in Porto Alegre $\left(\phi=30^{\circ} \mathrm{S}\right)$ and the lowest $(42.4 \%)$ in Belém $\left(\phi=1.4^{\circ} \mathrm{S}\right)$. In Porto Alegre $\left(\phi=30^{\circ} \mathrm{S}\right)$, Curitiba $\left(\phi=25.3^{\circ} \mathrm{S}\right)$, Belo Horizonte $\left(\phi=19.9^{\circ} S\right)$, and Brasilia $\left(\phi=15.7^{\circ} S\right)$ the irradiation harvested by East and West façades are similar to that received by a North façade, with variations below 5\%. Results indicate that those façades can be considered of the same importance concerning BIPV applications.

On the contrary, in Belém $\left(\phi=1.4^{\circ} \mathrm{S}\right)$, Teresina $\left(\phi=5^{\circ} \mathrm{S}\right)$ and Aracajú $\left(\phi=10.9^{\circ} S\right)$ the available annual global irradiation on vertical surfaces facing East and West ( $\cong 56 \%$ of the maximum) is between a $10 \%$ and a $14 \%$ higher than facing North. In fact, in Belém, due to its proximity to the Equator, the difference between solar resource in North and South façades is lower than $5 \%$. For other tilts in façades $\left(40^{\circ} \leq \beta \leq 90^{\circ} \mathrm{S}\right)$, acceptable amounts of solar irradiation have been observed, even for South orientations.

It is worth mentioning that, although $\leq 60 \%$, the available solar irradiation on façades in several of those cities has an annual value considerably high, compared to cities located in countries where this technology is already widespread, as can be seen in Fig. 13.

Note that an East/West façade in Belém $\left(\phi=1.4^{\circ} \mathrm{S}\right)$ only $56.3 \%$ of the global irradiation can be obtained, compared to an optimallyinclined-oriented surface. But it still means $1.039 \mathrm{kWh} / \mathrm{m}^{2} \mathrm{y}$, a considerably high amount of solar resource, in absolute terms 13\% less than the annual solar irradiation expected on a South façade in Madrid, Spain, and 14\% more than a South façade in Munich, Germany.

In the same way, Curitiba would have up to $839 \mathrm{kWh} / \mathrm{m}^{2}$ in a North oriented façade, representing just $6.2 \%$ less than a South façade in Munich, Germany. The reduced valor obtained in Curitiba can be explained by the availability of solar irradiation in that region, a monthly daily average irradiation of approximately $3.7 \mathrm{kWh} / \mathrm{m}^{2}$, the smallest in the country, and similar to the same parameter in Munich, of $3.14 \mathrm{kWh} / \mathrm{m}^{2}$.

These results are significant for the design of building envelope surfaces, not only vertical ones, but also inclined, like atriums and shading elements on façades and windows.

\section{Last considerations}

Remarking that, to raise the maximum amount of the available solar irradiation, it is also necessary to avoid or reduce losses to a minimum due to shading, cell temperature, dispersion, dirtiness, and wiring and DC/AC conversion - always a challenge in urban environments.

Indeed, state-of-the-art techniques for predicting the potential yield of solar applications in urban environments are available, almost all of them using similar calculation models to the ones used in this study, plus data from urban areas such as CAD maps or geographical information systems (GIS) [28-30]. They are been applied in solar urban planning in some North American and European cites [31-33], and been spread internationally by means of some projects currently ongoing $[34,35]$. They focus on identifying the available surfaces for solar active applications (thermal and photovoltaic) at urban scale, considering the exact location of buildings and the shadows that affect them.

With this article we aim to assess the solar potential resource on a general basis in different cities located in Brazil. Implementing a solar active system in a building requires, of course, a detailed analysis of the urban environment in which the building is located, using data from urban maps or, hopefully in the near future, from GIS data.

\section{Conclusions}

The analysis and results presented in this paper has made it possible to verify that, for the 78 Brazilian cities analyzed, the optimal tilt is almost always above the latitude value, up to $9^{\circ}$ more. An expression has been formulated to calculate the optimal tilt in the Brazilian latitudes, that is mathematically simple, with coefficient of determination $R^{2}=0.93$. This expression may be used as a simple tool for architects and design engineers to define the best tilt angle for preliminary building design.

The usage of the available global solar irradiation potential on building roofs $\left(0^{\circ} \leq \beta \leq 30^{\circ} \mathrm{S}\right)$ will be good, very good or optimal if faced North, East or West, and losses $\leq 15.0 \%$, compared to the maximum value for an optimally-inclined and oriented surface. If faced South, in latitudes from $0^{\circ}$ to $25^{\circ} \mathrm{S}$, they would also result in potential good yields, and would be intrinsically adequate for a wide range of building roof typologies.

Although horizontal roofs shall always give favorable yields, modules integrated in buildings shall be positioned with enough tilt in order to have the necessary rainfall runoff. That is especially important for cities with a high rainfall index, very common in Brazilian climate.

For non-vertical façades $\left(40^{\circ} \leq \beta \leq 90^{\circ} \mathrm{S}\right)$ the solar potential represents between $60 \%$ and $90 \%$ of the maximum global solar irradiation, even for South orientations, indicating that the use of 
sloped building envelope surfaces, such as atriums and shading elements on façades and windows should be promoted.

On vertical façades the availability of the solar resource is almost always below $60 \%$, regardless of their orientation in the cities studied. The best results have been observed on surfaces facing North for $15^{\circ} \mathrm{S} \leq \phi \leq 30^{\circ} \mathrm{S}$ and facing East/West for $1^{\circ} \mathrm{S} \leq \phi \leq 10^{\circ} \mathrm{S}$. Nevertheless, the resulting global irradiations presented quite high values, suggesting that the minimum threshold of $60 \%$ considered in European countries could be reconsidered in Brazil.

This shows that, contrary to general belief, the integration of PV technologies on vertical surfaces at low latitudes can be feasible and should always be considered.

The good solar irradiation availability for a wide range of orientations and tilts in Brazil becomes patently clear. It can be concluded that BIPV systems are appropriate not only on roofs, but also on façades for a large range of building typologies.

These results can also be used as a design tool for BIPV solutions which may allow handling higher PV power in a single building. We believe that in the mid-term it may influence the initial costs of these systems and make the construction of zero energy buildings feasible in Brazil.

\section{Acknowledgments}

This work is supported by the TISE Research Group and the UPM - Technical University of Madrid, through a research grant to carry out Ph.D. studies on the subject Design and Testing of Innovative Technical Solutions (Ref. CH/019/2008) in E.T.S. of Architecture, Department of Construction and Building Technology.

\section{References}

[1] R. Ruther, Experiences and operational results of the first grid-connected, building-integrated thin film photovoltaic installation in Brazil, in: Proceedings of the 2nd World Conference and Exhibition of Photovoltaic Solar Energy Convention, Vienna, Austria, 1998, pp. 2655-2658.

[2] A.D. Rosell, Un gigante dormido bajo el Sol, PHOTON: la Revista de Fotovoltaica 9 (2010) 88-111.

[3] http://www.americadosol.org/custos/, visited on 04.02.2012.

[4] R. Rüther, I. Salamoni, A. Montenegro, P. Brau, F.R. Devienne, Programa de telhados solares fotovoltaicos conectados à rede eléctrica pública no Brasil, in: XII Encontro Nacional de Tecnologia do Ambiente Construído, Fortaleza, Brasil, 2008.

[5] EPIA, European Photovoltaic Industry Association, Unlocking the Sunbelt Potential of Photovoltaics, Brussels, 2010.

[6] F.R. Martins, R. Rüther, E.B. Pereira, S.L. Abreu, Solar energy scenarios in Brazil. Part two: photovoltaics applications, Energy Policy 35 (2008) 2865-2877.

[7] C.S. Jardim, R. Rüther, I. Salamoni, T.S. Viana, S.H. Rebechi, P.J. Knob, The strategic siting and the roofing area requirements of building-integrated photovoltaic solar energy generators in urban areas in Brazil, Energy and Buildings 40 (2008) $365-370$.

[8] C.L. Chenga, C.Y. Chanb, C.L. Chena, Empirical approach to BIPV evaluation of solar irradiation for building applications, Renewable Energy 30 (2005) 1055-1074.
[9] J.A. Duffie, W.A. Beckman, Solar Engineering of Thermal Processes, third ed., Wiley, New York, 2006.

[10] K.K. Gopinathan, Solar radiation on variously oriented sloping surfaces, Solar Energy 47 (1991) 173-179.

[11] H. Gunerhan, A. Hepbasli, Determination of the optimal tilt angle of solar collectors for building applications, Building and Environment 42 (2007) 779-783.

[12] G. Lewis, Optimal tilt of solar collectors, Solar Wind Technology 4 (1987) 407-410.

[13] E. Lorenzo, Energy collected and delivered by PV modules, in: A. Luque, S. Hegedus (Eds.), Handbook of Photovoltaic Science and Engineering, Wiley, Great Britain, 2003, pp. 905-970.

[14] D. Prasad, M. Snow (Eds.), Designing with Solar Power: A Sourcebook for Building Integrated Photovoltaics (BIPV), The Images Publishing Group, Victoria, 2006.

[15] Gobierno de España. Código Técnico de la Edificación - HE5 Ahorro de Energía - Contribución Fotovoltaica Mínima de Energía Eléctrica, Spain, 2009.

[16] S. Roberts, N. Guariento, Building Integrated Photovoltaics - A Handbook, Birkhäuser, Basel, 2010.

[17] J.D. Mondol, Y.G. Yohanisa, B. Nortonb, The impact of array inclination and orientation on the performance of a grid-connected photovoltaic system, Renewable Energy 32 (2007) 118-140.

[18] C.L. Cheng, C.S.S. Jimenez, M. Lee, Research of BIPV optimal tilted angle, use of latitude concept for south orientated plans, Renewable Energy 34 (2009) 1644-1650.

[19] H.M.S. Hussein, G.E. Ahmad, H.H. El-Ghetany, Performance evaluation of photovoltaic modules at different tilt angles and orientations, Energy Conversion and Management 45 (2004) 2441-2452.

[20] I.H. Rowlands, B.P. Kemery, I. Beausoleil-Morrison, Optimal solar-PV tilt angle and azimuth: an Ontario (Canada) case-study, Energy Policy 39 (2011) 1397-1409.

[21] C.B. Christensen, G.M. Barker, Effects of tilt and azimuth on annual incident solar radiation for United States locations, in: Proceedings of Solar Forum (2001) Solar Energy: The Power to Choose, Washington, DC, 2001.

[22] M. Gutschner, S. Nowak, Approach to assess the solar yield differentiated photovoltaic area potential in the building, in: 2nd World Conference on Photovoltaic Solar Energy Conversion, Vienna, 1998.

[23] B. Weller, C. Hemmerle, S. Jakubetz, S. Unnewehr, Photovoltaics, first ed., Detail, Munich, 2010

[24] “World Radiation Data Centre." http://wrdc-mgo.nrel.gov (2010).

[25] B.Y.H. Liu, R.C. Jordan, The interrelationship and characteristic distribution of direct, diffuse and total solar radiation, Solar Energy 4 (1960) 1-19.

[26] M. Collares-Pereira, A. Rabl, The average distribution of solar radiation correlations between diffuse and hemispherical and between daily and hourly insolation values, Solar Energy 22 (1979) 155-164.

[27] R. Perez, et al., A new simplified version of the Perez diffuse irradiance for tilted surfaces, Solar Energy 39 (1987) 221-231.

[28] S. Gadsden, M. Rylatt, K. Lomas, D. Robinson, Energy efficiency and solar energy in urban planning: a GIS-based decision support prototype for the domestic sector, in: Proceedings of PLEA 2000, Cambridge, UK, 2000, pp. 672-677.

[29] B. Sorensen, GIS management of solar resource data, Solar Energy Materials and Solar Cells 67 (2001) 503-509.

[30] J. Hofierka, J. Kaňuk, Assessment of photovoltaic potential in urban areas using open-source solar radiation tools, Renewable Energy 34 (2009) 2206-2214.

[31] L. Bergamasco, P. Asinari, Scalable methodology for the photovoltaic solar energy potential assessment based on available roof surface area: application to Piedmont Region (Italy), Solar Energy 85 (2011) 1041-1055.

[32] http://www.planen-mit-der-sonne.de/cms/startseite/willkommen.html (accessed 01.04.2012).

[33] http://www.stadtentwicklung.berlin.de/umwelt/umweltatlas/d806_03.htm \#top (accessed 01.04.2012).

[34] http://www.polis-solar.eu/ (accessed 01.04.2012).

[35] http://www.huellasolar.com/?page_id=149 (accessed 01.04.2012). 